\title{
Jurnalis dan Jurnalisme dalam Fenomena Kontemporer
}

\author{
Pandan Yudhapramesti \\ Fakultas Ilmu Komunikasi Universitas Padjadjaran
}

Secara global, jurnalisme telah berkembang dari waktu ke waktu, sejalan dengan perubahan berbagai aspek dalam masyarakat, seperti sosial, budaya, politik, agama, ekonomi, termasuk teknologi komunikasi. Demokrasi sering menjadi kambing hitam keterbatasan ruang gerak pers atau praktik-praktik jurnalisme. Di Indonesia, runtuhnya orde baru telah memberikan kesempatan bagi pers yang lebih demokratis. Namun eksistensi pers, jurnalisme, serta jurnalis-jurnalis yang berkecimpung di dalamnya justru terancam melemah karena kelemahan beradaptasi pada perkembangan teknologi informasi dan komunikasi (TIK). Di n'egara-negara dengan tingkat konektivitas internet yang baik, internet telah mengubah cara orang-orang berkomunikasi secara dramatis. Terjadi dialektika antara perkembangan TIK dan perubahan sosial, termasuk pada perubahan cara-cara produksi dan konsumsi media, serta berubahnya praktik-praktik jurnalisme dalam berbagai aspek. Kondisi ini memunculkan pertanyaan, jika orang orang telah demikian mudah saling bertukar informasi, masihkah jurnalisme diperlukan? Jurnalisme hanya akan tetap eksis bila mampu beradaptasi dan responsif terhadap perubahan. Makalah ini menyoroti berbagai fenomena kontemporer terkait adaptasi terhadap perubahan tersebut mencakup a) spirit, ideologi, dan pendekatan; b) kemampuan menggali, mengolah karya, dan menyampaikan karya kepada khalayak, c) pemahaman tentang medium penyampai pesan, d) pemahaman atas perilaku khalayak serta nilai-nilai yang berlaku dalam masyarakat baik dalam konteks lokal maupun global. Kemampuan beradaptasi pada elemen-elemen perubahan tersebut akan menentukan eksis tidaknya jurnalisme.

Kata kunci : Jurnalisme, kontemporer, adaptasi perubahan

Secara global, jurnalisme telah berkembang dari waktu ke waktu, sejalan dengan perubahan berbagai aspek dalam masyarakat, seperti aspek sosial, budaya, politik, ekonomi, termasuk teknologi komunikasi. Perkembangan jurnalisme bahkan mengalami percepatan dalam tahun-tahun terakhir, terutama sejak internet digunakan sebagai basis komunikasi standard. Di negara-negara dengan tingkat konektivitas internet yang baik, internet telah mengubah cara orangorang berkomunikasi secara dramatis.
Perubahan cara berkomunikasi ini berdampak pada perubahan cara-cara produksi dan konsumsi media, termasuk pada berubahnya praktik-praktik jurnalisme dalam berbagai aspek. Jurnalisme hanya akan tetap eksis bila "ia" mampu beradaptasi dan responsif terhadap perubahan.

Teori-teori tentang media dan masyarakat modern pada era sebelum internet berkembang menyebutkan bahwa media berfungsi sebagai penyampai warisan sosial, dimana media ikut 
menyampaikan informasi, nilai, dan norma dari satu generasi ke generasi berikutnya, atau dari anggota masyarakat ke kaum pendatang (Rivers, etc, 2008). Secara positif, media disebut-sebut sebagai penjaga nilai-nilai dalam masyarakat. Meski pada waktu yang bersamaan pandangan ini juga selalu ditentang oleh pihak yang mengatakan bahwa justru media lah yang secara agresif merusak tata nilai dalam masyarakat.

Berkembangnya teknologi internet telah membuat orang-orang biasa dapat berkomunikasi secara langsung, khususnya setelah era media sosial berkembang pesat. Kondisi ini membuat posisi jurnalis dan jurnalisme berubah. Sebelumnya, jurnalis adalah orang yang harus selalu tahu lebih dulu tentang fakta atau peristiwa yang bernilai penting atau menarik bagi masyarakat. Khalayak selalu menunggu kabar terbaru yang secara rutin dihadirkan oleh media massa. Internet telah mengubah banyak hal, dalam konteks tertentu bahkan telah mengembalikan cara orang-orang biasa berkomunikasi kepada cara-cara lama, masyarakat tutur, yang berkomunikasi secara langsung antar orang-orang. Bedanya, dulu orang berkomunikasi langsung dengan cara lisan. Kini, orang berkomunikasi langsung melalui alat bantu teknologi komunikasi berbasis internet. Orang-orang biasa dapat memperoleh informasi atau berita tanpa dijembatani oleh media massa. Kondisi ini memunculkan pertanyaan, jika orang orang telah demikian mudah saling bertukar informasi, masihkah jurnalisme diperlukan?

Selain internet, tentu saja banyak faktor yang telah membuat kebutuhan masyarakat terhadap jurnalisme berubah atau berkembang. Kebutuhan masyarakat berubah karena perubahan dalam masyarakat, serta perubahan dalam sisi jurnalismenya itu sendiri. Menjadi tantangan bagi para pelaku di bidang jurnalisme, khususnya para jurnalis untuk dapat beradaptasi dengan berbagai aspek perubahan, agar bisa tetap eksis di masyarakat.

\section{Fenomena Kontemporer Dalam Praktik Jurnalisme}

Dinamika jurnalisme telah terjadi sejak praktik jurnalisme itu terjadi, sejak praktik jurnalisme masih berlangsung dengan cara-cara yang sangat sederhana sebagai cara penyampaian informasi yang dinilai penting bagi masyarakat. Dinamika kemasyarakatan, seperti aspek sosial budaya, agama, politik, ekonomi, teknologi, serta demokrasi kemudian akan memengaruhi bagaimana praktik jurnalisme itu berlangsung. Relevansi dan eksistensi jurnalisme bagi masyarakat terkait berbagai pertanyaan berikut :

- Apakah praktik jurnalisme mampu memenuhi kebutuhan masyarakat akan informasi/berita?

- Apakah pelakunya (jurnalis) dapat dipercaya?

- Apakah karya yang dihasilkannya cukup menarik dan berkualitas?

- Apakah praktik jurnalisme memberi kesempatan bahkan secara aktif dan kreatif mengajak orang-orang untuk terlibat? Apakah praktik jurnalisme akan berlangsung dengan cara-cara top down atau bottom up, apakah jurnalisme akan dapat menjalankan fungsi sebagai saluran berekspresi yang adil dan fair bagi semua kalangan.

Sebagai contoh, sejarah sosial politik di Indonesia pada masa transisi orde baru ke era reformasi telah memperkuat fungsi pers dan jurnalisme, termasuk kesempatan yang diperoleh para jurnalis untuk meningkatkan kompetensi dan kapasitas mereka. Demokrasi sering menjadi kambing hitam keterbatasan ruang gerak pers atau praktik-praktik jurnalisme. Runtuhnya orde baru telah memberikan kesempatan bagi pers yang lebih demokratis. Namun eksistensi pers, jurnalisme, serta jurnalis-jurnalis yang berkecimpung di dalamnya justru terancam melemah seiring dengan kemajuan teknologi komunikasi jika tidak diiringi kemampuan untuk beradaptasi dalam perubahan. 
Pertanyaan tentang eksistensi jurnalisme menjadi signifikan dengan temuan data yang menunjukkan merosotnya jumlah pembaca media cetak atau pendengar siaran radio (Lim, 2011). Di banyak negara berkembang termasuk Indonesia, televisi masih menjadi media primadona masyarakat. Namun tidak demikian dengan negara maju. Tingkat konektivitas internet serta tingkat melek informasi dan media yang baik ikut memengaruhi merosotnya jumlah audience media konvensional.

Tabel 1 Presentase Populasi Terkait Aktivitas Bermedia

\begin{tabular}{|l|c|c|c|}
\hline & $\mathbf{2 0 0 3}$ & $\mathbf{2 0 0 6}$ & $\mathbf{2 0 0 9}$ \\
\hline Menonton TV & $84.94 \%$ & $85.86 \%$ & $90.27 \%$ \\
\hline Mendengarkan Radio & $50.29 \%$ & $40.26 \%$ & $23.50 \%$ \\
\hline Membaca Surat Kabar & $23.70 \%$ & $23.46 \%$ & $18.94 \%$ \\
\hline & \multicolumn{2}{|c|}{$\begin{array}{c}\text { Frekuensi menggunakan media } \\
\text { perminggu untuk mengakses berita }\end{array}$} \\
\hline Televisi & $95 \%$ & $97 \%$ & $97 \%$ \\
\hline Radio & $50 \%$ & $44 \%$ & $35 \%$ \\
\hline Surat Kabar & $\mathbf{2 2 \%}$ & $17 \%$ & $16 \%$ \\
\hline Internet/On line & $\mathbf{2 \%}$ & $3 \%$ & $4 \%$ \\
\hline SMS & $6 \%$ & $5 \%$ & $9 \%$ \\
\hline
\end{tabular}

Banyak faktor menjadi penyebab merosotnya jumlah audiens. Namun fakta ini setidaknya menjadi alasan kuat untuk para pelaku jurnalisme khususnya jurnalis, untuk mempertanyakan kembali apa yang dibutuhkan dari audiens yang dilayaninya selama ini. Untuk itu, makalah ini menyoroti berbagai hal terkait fenomena kontemporer dalam jurnalisme yang patut menjadi perhatian kita, menyangkut a) spirit, ideologi, dan pendekatan; b) kemampuan menggali, mengolah karya, dan menyampaikan karya kepada khalayak, c) pemahaman tentang medium penyampai pesan, d) pemahaman atas perilaku khalayak serta nilai-nilai yang berlaku dalam masyarakat baik dalam konteks lokal maupun global. Penelitian dilakukan melalui penelusuran kepustakaan (library research) dari berbagai sumber relevan terkait jurnalisme kontemporer, berupa buku, jurnal ilmiah, serta berbagai dokumen elektronik.

\section{a) Jurnalisme : Spirit, Ideologi, dan Pendekatan}

Jurnalisme harus memiliki orientasi untuk apa dan untuk siapa ia ada. Untuk itu jurnalisme harus memiliki spirit, ideologi, serta misi. Tentu saja spirit, ideologi, serta misi yang dimaksud menyangkut landasan yang baik bagi praktik jurnalisme yang sehat. Bukan ideologi atau misi pemilik media yang menggunakan medianya sebagai alat untuk memenuhi kepentingan kelompok tertentu.

Seiring dengan dinamika masyarakat, praktik jurnalisme tidak cukup sekedar menyampaikan kabar-kabar penting pada masyarakat. Beberapa pelajaran berharga menunjukkan bahwa praktik jurnalisme 
tanpa spirit atau ideologi yang kuat justru dapat menjadi bumerang. Sebut saja jurnalisme perang yang mengabarkan berita kemenangan atau kekalahan antar pihak yang berperang, seperti yang pernah dilakukan beberapa media besar pada perak Irak Amerika di awal tahun 2000 lalu. Praktik jurnalisme perang seperti ini, awalnya terasa menarik, terbukti dari pencapaian rating atau oplah media yang cukup tinggi. Namun akhirnya malah menimbulkan kesadaran tentang betapa praktik-praktik seperti itu malah memancing konflik susulan dan memperkeruh suasana.

Kesadaran ini kemudian memunculkan gerakan penyadaran tentang perlunya pendekatan damai atau advokasi dalam praktik jurnalisme. Istilah jurnalisme damai kemudian muncul. "Peace journalism" is the approach to the practice of the trade with an underlying philosophy to bring about the reduction of violence, especially when tensions flare between ethnicities, to moderate the politically stifling impasse, and to promote dialogue between antagonists where embedded suspicion threatens to disrupt already fragile communities (Obonyo \& Fackler1, 2009). Selain jurnalisme damai, juga dikenal istilah jurnalisme publik, jurnalisme advokasi, atau Civic Advocacy Journalism (CAJ) "As a social development -oriented type of journalism is deeply entrenched in the principle of media and morality" (Raposas). Roger Silverstone (dalam Raposas) dalam bukunya Media and Morality menggarisbawahi perlunya moralitas media dalam konteks yang lebih luas dan lebih global. Buah pikirnya adalah contoh langsung praktek CAJ yang memberikan dorongan bagi wartawan untuk melihat ke dalam hati nurani dan moralitas mereka saat mereka melaporkan peristiwaperistiwa global dan dampaknya terhadap kemanusiaan.

Selain jurnalisme damai ataupun jurnalisme advokasi, belakangan muncul pula pendekatan pro lingkungan dalam praktik jurnalisme. Kesadaran tentang upaya-upaya konservasi atau penghematan energi, menghitung jejak karbon, menunculkan pendekatan pro lingkungan. Jurnalisme lingkungan sebagai sebuah spirit atau pendekatan tidak melulu berbicara tentang lingkungan hidup secara langsung. Jurnalisme berorientasi lingkungan dapat membahas berbagai topik dari perspektif keseimbangan lingkungan hidup. Sebagai contoh, topik-topik seperti rancangan anggaran belanja negara dapat ditinjau dari perspektif lingkungan, dalam arti bagaimana dampak rencana pembangunan dan penganggarannya terhadap keseimbangan lingkungan hidup. Apakah rencana pembangunan jalan tol baru akan merusak ekosistem yang ada di sekitarnya, dan sebagainya.

\section{b) Kemampuan Menggali dan Mengolah Karya}

Secara tradisional, pada awal masa kerjanya, seorang jurnalis biasanya telah diajari cara-cara memperoleh informasi seperti melalui cara paper trail, people trail, elektronic trail termasuk belakangan internet trail. Hal penting yang harus disadari oleh jurnalis adalah seberapa valid informasi yang telah diperolehnya. Untuk itu jurnalis perlu disiplin melakukan verifikasi atas informasi yang diperolehnya.

Meski teknologi informasi dan komunikasi terus berkembang, sesungguhnya fungsi mendasar jurnalis saat menggali dan mengolah data tetaplah sama. Jurnalis harus menggali semua data yang relevan dengan topik yang ia kerjakan. Namun, perkembangan teknologi informasi dan komunikasi kemudian memperkaya dan mengembangkannya menjadi teknikteknik yang lebih mutakhir.

Pada saat melakukan peliputan, hal substansial yang perlu dipahami dan dikuasai dengan baik oleh jurnalis adalah kemampuan untuk menggali, mengolah, dan menyajikan data. Teknologi komunikasi dan informasi yang tersedia saat ini mendukung ketersediaan data yang sangat kaya yang sering diberi istilah big data. Limpahan data mengalir setiap waktu, tersedia dalam berbagai bentuk, mulai dari data yang hanya merupakan kumpulan angka hingga data yang telah diolah menjadi cerita. Semua data tersebut 
merupakan bahan baku yang berlimpah bagi jurnalisme (Bell, 2012). Big data memicu perkembangan perangkat untuk mengumpulkan dan menganalisis data. Analisisnya akan bergantung pada kejelian terhadap angka dan kemahiran menggunakan perangkat pada komputer. Sebagai contoh, data gempa, tak hanya diperoleh dari Badan Meteorologi, Klimatologi dan Geofisika (BMKG) atau United States Geological Survey (USGS), tetapi juga bisa diperoleh dari Google Earth. Pada kasus gempa bumi yang memicu bencana nuklir Fukushima pada tahun 2011, NHK Jepang menemukan fakta awal melalui data angka dan statistik bahwa penjualan air meningkat tajam sehari setelah gempa. Sempat terjadi penurunan selama enam hari kemudian, penjualan air kembali naik tujuh hari setelah gempa.Temuan itu dapat memberi gambaran tentang kekhawatiran warga Tokyo akan radiasi nuklir setelah gempa (Utomo, 2015).

Data tersebut telah melewati proses yang panjang, diperoleh dari berbagai sumber, dari saksi mata yang mengalami, melewati berbagai filter dari berbagai jaringan sosial, memperoleh berbagai tanggapan, pemeringkatan, dan sebagainya. Limpahan data yang luar biasa bahkan membuat sebagian data terabaikan begitu saja. Teh atau kopi yang kita minum di pagi hari, bukan sekedar secangkir teh atau kopi, namun dapat terkait dengan persoalan ekonomi gobal yang menghubungan antara produk-produk teh atau kopi tersebut dengan orang-orang di berbagai belahan dunia. Dibalik kelezatan secangkir kopi, mungkin saja terdapat cerita mengenaskan tentang orang-orang yang menjadi korban per dagangan manusia dan dipaksa menjadi buruh pemetik kopi di belahan dunia yang lain, yang sangat jauh dari tempat secangkir kopi itu disajikan.

Itu sebabnya data bahkan big data menjadi sangat penting bagi jurnalis. Jurnalis harus memiliki kemampuan untuk memperoleh data dari berbagai sumber, mengerti status atas data yang diperolehnya - misalnya apakah data tersebut termasuk data yang boleh dipublikasikan atau tidak, mempu mengolahnya, dan menyajikan (memvisualisasikan) apa yang terjadi secara baik sehingga menjadi mudah dan menarik untuk dicerna. Akses kepada data memiliki potensi untuk memperjelas sebuah masalah dan cara mengatasinya. Penanganan yang buruk terhadap data dapat menyebabkan kegagalan untuk memberikan pemahaman kontekstual dan tidak memberikan banyak arti kepada publik. Selain harus bisa menggali data yang dibutuhkan, memilih sumber informasi terpercaya saat menggali data, melakukan klasifikasi dan analisis yang baik, Jurnalis harus bisa menempatkan data yang diperolehnya pada konteks yang tepat. Misalnya, data apa saja yang diperlukan untuk memahami kemiskinan di sebuah daerah. Apakah cukup dengan data pendapatan perkapita, atau juga harus dilengkapi dengan data lain seperti perbandingan dengan harga bahan kebutuhan pokok serta skala prioritas penggunaan uang bagi kelompok masyarakat tertentu. Setelah data diperoleh, tentu saja data kemudian harus diolah dan disajikan dalam bentuk kisah. Start with the data, finish with a story (Gregor Aisch, 2011). Big data yang tersedia melalui internet membuat pemerolehan data berlangsung dengan lebih mudah dan murah, namun semua proses ini tentu saja harus dilakukan dalam koridor etika (Fairfield \& Shtein, 2014).

Penggalian dan pengelolaan data tidak hanya dapat dilakukan sendiri atau sekelompok jurnalis. Jurnalis atau sebuah tim redaksi juga dapat secara terstruktur untuk mengajak khalayak terlibat aktif dalam pencarian informasi. Dengan kata lain data dapat diperoleh dengan cara crowdsourcing, kolaborasi antara jurnalis dan khalayak, karena ini adalah era interaktivitas. Point penting dari crowdsourcing adalah untuk memanfaatkan kecerdasan kolektif, bukan hanya mengumpulkan konten dari para penyumbang informasi atau memanfaatkan jurnalisme warga (Vehkoo, 2013)

The Guardian dan BBC merupakan dua lembaga besar yang memiliki pengalaman melakukan crowdsourcing, sebuah proyek kolaborasi antara media dan khalayak untuk bersama-sama 
mengumpulkan data - lalu kemudian menganalisisnya - tentang sebuah persoalan publik.

Di Indonesia, beberapa media seperti Radio Suara Surabaya juga telah memiliki pengalaman panjang mengumpulkan informasi dari pendengar untuk kemudian mengolahnya ke dalam sebuah isu besar terkait kepentingan publik.

Saat ini telah muncul berbagai kampanye untuk meningkatkan pemahaman dan kesadaran jurnalis terhadap data. Seperti yang dilakukan oleh Open Khowledge Foundation (https://okfn.org/. Ada juga aplikasi khusus yang diciptakan seperti Analice.me (http://ijnet.org/blog/analicemeplatform-helps-journalists-automaticallyanalyze-thousands-documents) yang dapat membantu jurnalis menganalisis ribuan dokumen secara cepat. Sementara google saat ini telah membangun google newslab untuk memfasilitasi data yang tersedia secara global bagi jurnalis dari berbagai belahan dunia. Untuk menjamin kualitas data, google menjalin kerja sama dengan lembaga yang menyediakan melakukan validasi dan verifikasi data seperti storyful atau firstdraft.

Saat ini terdapat berbagai istilah dalam berbagai teknik penggalian informasi, seperti teknik investigasi, teknik advokasi, teknik kurasi atas informasi. Penting untuk dapat membedakan istilah teknik investigasi sebagai sebuah teknik penggalian informasi dengan jurnalisme investigasi sebagai sebuah genre. Seperti halnya penting untuk membedakan istilah teknik advokasi dengan genre jurnalisme advokasi, serta teknik kurasi dengan jurnalisme kurasi. Teknik investigasi ini dapat saja dipakai oleh kepolisian, detektif, bahkan kru program reality show untuk menguji kebenaran sebuah informasi. Informasi yang hendak digali dapat terkait dengan kepentingan publik, namun bisa juga hanya terkait dengan kepentingan pihak tertentu saja. Untuk dapat dikatakan sebagai sebuah genre, seperti dinyatakan seorang wartawan senior di Indonesia, Farid Gaban, jurnalisme investigasi sering dinyatakan sebagai "Journalism with an impact" dan "Reporting on public interest issues".
Untuk mencapai "impak" yang dimaksud, jurnalisme investigasi menuntut: Pembahasan yang komprehensif (dengan konteks dan background), proses verifikasi yang matang (tak ada tanda tanya, tak ada lagi kata "konon" atau "kabarnya"), Mementingkan menjawab "how" dan "why" dari elemen $5 \mathrm{~W}-1 \mathrm{H}$, penulisan yang populer, lugas dan gamblang (Gaban).

Teknik advokasi juga biasa dilakukan pada peliputan beberapa isu. Sebagai contoh, saat meliput dan memberitakan kasus perdagangan manusia, sengaja atau tidak sengaja, seorang jurnalis atau sebuah tim pemberitaan dapat ikut melakukan advokasi terhadap kasus tersebut. Saat peliputan, seorang jurnalis dapat menyampaikan kepada kepolisian tentang praktik perdagangan manusia yang ia temukan, sekaligus meminta kepolisian untuk langsung menangani kasus tersebut. Praktik advokasi biasanya terjadi pada kasus pemberitaan dimana pihak yang diberitakan membutuhkan pertolongan dari jurnalis ataupun pembaca/khalayak. Kisah Prita Mulyasari merupakan salah satu kasus advokasi yang berasal dari pemberitaan. Seperti halnya teknik investigasi, teknik advokasi tidak serta merta menjadi bagian dari genre jurnalisme advokasi.

\section{Story in Perspective}

Tidak mudah menjelaskan istilah ini dalam padanan Bahasa Indonesia yang pas. Story in perspective yang dimaksud bukanlah angle atau sudut pandang cerita, melainkan sebuah perspektif atas sebuah objek yang akan dibahas. Berbagai contoh akan dapat menjelaskan istilah tersebut dengan lebih baik. Sebut saja rencana pembangunan jalan tol, dapat dibahas dari berbagai perspektif. Melalui perspektif ekonomi, kita dapat menghitung untung rugi pembangunan jalan tol dari kaca mata ekonomi. Berapa total uang yang mengalir pendapatan jalan tol dibandingkan dengan sebelum jalan tol itu terbangun. Katakanlah misalnya sebelum.jalan tol itu terbangun hanya ada tanah gersang dan sebagian ladang. Maka uang yang mengalir setelah jalan tol dibangun akan meningkat berlipat ganda. 
Masyarakat sekitar jalan tol pun dapat memetik manfaat, memperoleh mata pencaharian dengan bekerja di rest area, sehingga kesejahteraan mereka menjadi lebih baik dibanding sebelumnya dengan hanya mengolah ladang yang kering dan gersang.

Melalui perspektif arsitektur atau penataan ruang kita bisa membahas kualitas konstruksi jalan tol dan keseimbangannya dalam penataan ruang kota. Kisah jalan tol Cipularang sudah banyak diliput sebagai kisah sukses para ahli dari Indonesia yang mampu membangun sendiri jalan tol yang panjang, berkualitas, dan indah. Namun dari perspektif transportasi, pembangunan jalan tol hanya memindahkan masalah menjadi masalah baru. Jalan tol Cipularang pada awalnya membuat waktu tempuh perjalanan Jakarta Bandung menjadi lebih singkat, dari semula empat hingga lima jam melalui jalan biasa, menjadi dua hingga tiga jam melalui tol Cipularang. Namun jalan tol juga merangsang orang untuk semakin banyak menggunakan mobil sehingga waktu tempuh Jakarta Bandung kini seringkali sudah lebih dari lima jam karena macet. Itu sebabnya bertahuntahun lalu ketika rencana pembangunan jalan tol diluncurkan, sejumlah ahli transportasi menolak rencana pembangunan tersebut dan lebih menyarankan penguatan pembangunan transportasi berbasis kereta api untuk mencegah kemacetan. Sayangnya pendapat para ahli transportasi ini malah kalah dibandingkan pendapat dari para ahli di bidang lain.

Dari perspektif lingkungan hidup, kita bisa membahas dampak pembangunan jalan tol terhadap lingkungan hidup. Sementara kita juga bisa membahas dampak pembangunan jalan tol terhadap perubahan sosial budaya masyarakat sekitar, seperti perubahan mata pencaharian, perubahan ritme hidup, dan sebagainya. Cerita tentang secangkir kopi dapat menjadi kisah tentang resep membuat secangkir kopi yang enak, atau menjadi liputan tentang strategi bisnis, atau liputan tentang kajian budaya tentang gaya hidup kelompok masyarakat tertentu yang sangat bergantung pada budaya minum kopi. Topik tentang transgender dapat dibahas dari perspektif medis atau agama.

Sebuah liputan tentu saja dapat mengandung berbagai perspektif. Seperti menggabungkan perspektif bisnis dan sosial budaya pada liputan jalan tol atau kopi. Namun gabungan dari berbagai perspektif mungkin akan membuat sebuah liputan menjadi terlalu panjang, berat, atau membosankan untuk dinikmati. Sering pula terjadi kebijakan redaksi membatasi pilihan perspektif cerita. Jurnalis harus mampu menentukan perspektif yang tepat atas sebuah topik yang ia liput dan ia sajikan, sehingga kisah tersebut menjadi bernilai bagi khalayak.

\section{c) Pemahaman tentang Medium Penyampai Pesan}

Internet sudah bukan lagi hal baru bahkan bagi negara berkembang seperti Indonesia. Penggunaannya meningkat terus. Sementara, di sisi lain, data tentang menurunnya khalayak media konvensional seperti pembaca surat kabar atau pendengar radio, juga sudah diketahui para pengelola media termasuk jurnalis. Pekerjaan rumah bagi para jurnalis adalah menganalisis kondisi ini dengan baik.

Perilaku khalayak dan medium penyampai pesan adalah sebuah hubungan timbal balik. Perilaku khalayak digerakkan oleh karakteristik medium. Sebaliknya karakteristik medium juga dapat digerakkan oleh kebutuhan khalayak. Pengelola media dapat memperlakukan khalayaknya sebagai khalayak yang pasif atau aktif. Pembaca surat atau penonton televisi kabar pada umumnya cenderung menjadi penikmat yang pasif. Hanya sedikit pembaca yang kemudian tergerak dan mampu untuk berkontribusi menulis surat pembaca atau artikel. Demikian juga pada televisi, hanya sedikit kesempatan yang diberikan televisi untuk interaksi dengan penonton melalui keterlibatan langsung dalam berbagai acara siaran. Sedikit berbeda dengan radio siaran. Pada umumnya radio siaran memberikan kesempatan khalayaknya untuk lebih aktif terlibat dalam berbagai 
acara siaran dalam kesempatan untuk meminta lagu, berkomentar dalam acara siaran talkshow.

Kondisi yang sama sekali berbeda terjadi pada media berbasis internet. Internet dapat menyampaikan pesan dalam berbagai bentuk : teks, gambar, audio, video, atau kombinasi dari sebagian atau semuanya - secara langsung. Ketersediaan ini dapat menggerakan pengakses internet untuk mengakses bentuk pesan tertentu saja atau kombinasi dari sebagian atau semuanya. Hal yang tidak kalah penting yang perlu dipahami medium berbasis internet adalah karakter interaktivitas. Setiap orang yang terhubung dapat menjadi konsumen sekaligus produsen pesan. Banyak orang mencoba menggunakan internet untuk menyampaikan atau saling bertukar pesan, menggunakan media sosial, dengan membangun blog, web site, mengembangkan aplikasi tertentu, membangun media start up dan sebagainya. Hanya sebagian bahkan sebagian kecil yang bisa bertahan. Mereka yang bisa bertahan pada umumnya adalah orang yang memahami betul apa yang dibutuhkan khalayak atau kelompok orang yang dilayaninya. Dengan kata lain, jurnalis harus mampu menawarkan value bagi khalayak, dengan cara-cara yang dibutuhkan dan disukai khalayak.

Sebuah karya dapat berbentuk karya teks saja, gambar saja, audio saja, video saja, atau kombinasi dari sebagian bentuk tersebut, atau kombinasi dari semuanya. Sebuah kajian yang dilakukan Mindy McAdams menyebutkan sebuah karya yang dibuat dalam beragam format atau multimedia journalism akan lebih punya daya tarik bagi khalayak. "Transmedia storytelling is an option for stories that have a sufficiently broad scope to justify expansions on different platforms. If a multimedia journalism project includes video, text, and interactive apps, journalists should be thinking about how to extend and expand that story on other platforms (McAdams, 2014). d) Pemahaman Tentang Perilaku Khalayak Serta Nilai-Nilai Yang Berlaku Dalam Masyarakat Baik Dalam Konteks Lokal Maupun Global

Jurnalistik merupakan serangkaian aktivitas yang bersifat melayani masyarakat. Karya yang dihasilkan merupakan hasil akhir yang akan diberikan untuk masyarakat (atau kelompok masyarakat tertentu). Media massa besar biasanya memiliki data tentang karakteristik khalayaknya, baik data demografis, geografis, psikografis, maupun perilaku atau kebiasaan khalayak mengakses media. Meski jurnalis bekerja dalam media kecil atau bahkan bekerja mandiri, jurnalis seyogyanya memiliki pengetahuan yang baik atas khayalak yang dilayaninya atau target khalayaknya.

Agar mampu memilih data yang pantas disajikan, menentukan perspektif atas kisah yang diolah, jurnalis harus mampu memahami nilai-nilai yang berlaku di masyarakat. Tentu tidak mudah melaksanakan hal ini, mengingat tatanan atau nilai, etika, juga hukum yang berlaku dalam sebuah kelompok masyarakat berbeda dengan masyarakat lainnya. $\mathrm{Hal}$ yang dianggap ringan dan biasa saja bagi sebuah kelompok masyarakat, mungkin menjadi hal yang tabu bagi kelompok masyarakat lainnya. Untuk itu jurnalis harus memiliki kemampuan untuk meletakkan sebuah isu pada konteks yang tepat. Topik-topik tertentu seperti transgender atau topik yang mengandung konflik dapat menjadi isu yang sulit untuk diolah. Pemahaman tentang nilai yang berlaku di kalangan masyarakat tertentu dapat membantu jurnalis untuk menentukan perspektif serta meletakkan isu tersebut pada konteks yang tepat. 


\section{Reposisi Jurnalis dan Jurnalisme}

Ketersediaan teknologi komunikasi dan informasi telah mengubah perilaku produksi dan konsumsi media. Khalayak kini tidak lagi pasif. Khalayak tidak saja dapat aktif memilih informasi, mereka juga dapat mengolah dan menghasilkan informasi. Beberapa pengalaman sukses yang telah diceritakan dalam tulisan ini menunjukkan bahwa jurnalisme tetap menarik jika mampu memberikan value atau kemanfaatan bagi khalayak. Jurnalisme tetap menggairahkan bagi khalayak jika memberikan peluang bagi khalayak untuk ikut berpartisipasi. Untuk itu jurnalis harus menjalankan fungsi literasi bagi khalayak. Khalayak dapat diajak berkolaborasi mengumpulkan informasi, jurnalis kemudian mengolah dan menyajikan informasi yang terverifikasi. Jurnalis bisa tetap bekerja dalam media massa, namun ia dapat bekerja secara individu dan independen. Sebuah prediksi pernah disampaikan oleh Roger Fidler dalam bukunya Mediamorfosis yang pertama kali terbit pada akhir tahun 9oan, bahwa teknologi digital tidak disangsikan lagi akan memenuhi kebutuhan konsumen yang semakin meningkat, atas informasi yang sesuai untuk setiap pribadi, namun semua itu tidak akan menghapuskan perlunya penilaian dan analisis manusia. Ini berarti kebutuhan akan profesional media cenderung meningkat. Namun jurnalis masa depan pasti membutuhkan keterampilan yang semakin bertambah dalam penguasaan teknologi (Fidler, 2003). Prediksi tersebut ternyata terbukti hingga puluhan tahun sesudahnya. Jurnalis dan jurnalisme dapat tetap eksis hanya bila ia adaptif dan responsif terhadap perubahan. 


\section{Daftar Pustaka}

Bell, E. (2012, September/October). Journalism by Numbers. Columbia Journalism Review. Retrieved 12 20,2015 , from http://web.a.ebscohost.com/ehost /pdfviewer/pdfviewer?sid=5cba2c 35-97a6-44f1-b11466c12e2193od\%40sessionmgr400 $3 \&$ vid $=6 \&$ hid $=4109$

Fairfield, J., \& Shtein, H. (2014). Big Data, Big Problems : Emerging Issues in The Ethics of Data Sciences in Journalism. Journal of Mass Media Ethics, 29-38-51.

Fidler, R. (2003). Mediamorfosis. Bentang Budaya.

Gaban, F. (n.d.). Retrieved from http://www.jurnalistik.net/: http://www.jurnalistik.net/wpcontent/uploads/groupdocuments/5/1317201396LiputanInvestigatif.pdf

Gregor Aisch, e. (2011). The Data Journalism Handbook : How Journalist Can Used Data to Improve The News. Open Khowledge Foundation.

Lim, M. (2011). @crossroads: Democratization \& Corporatization of Media. Participatory Media Lab at Arizona State University \& Ford Foundation.
McAdams, M. (2014). Chapter from Ethics for Digital Journalists (Routledge) Multimedia. Routledge.

Obonyo, L., \& Fackler1, M. (2009). World Journalism Educators Congress (WJEC). Grahamstown South Africa.

Raposas, M. Q. (n.d.). Retrieved from http://www.divaportal.org/smash/get/diva2:37767 7/FULLTEXTo1.pdf

Rivers, etc, W. E. (2008). Media Massa dan Masyarakat Modern. Kencana.

Utomo, Y. W. (2015, 06 15). Statistika, Komputer, dan Jurnalisme Masa Depan. Retrieved 12 20, 2015, from http://sains.kompas.com/read/20 15/06/15/13021221/Statistika.Ko mputer.dan.Jurnalisme.Masa.Dep an

Vehkoo, J. (2013). Crowdsourcing in Investigative Journalism. Routers Institute for The Study of Journalism. Retrieved from http://reutersinstitute.politics.ox.a c.uk/sites/default/files/Crowdsour cing\%20in\%2oInvestigative\%20Jo urnalism_o.pdf 